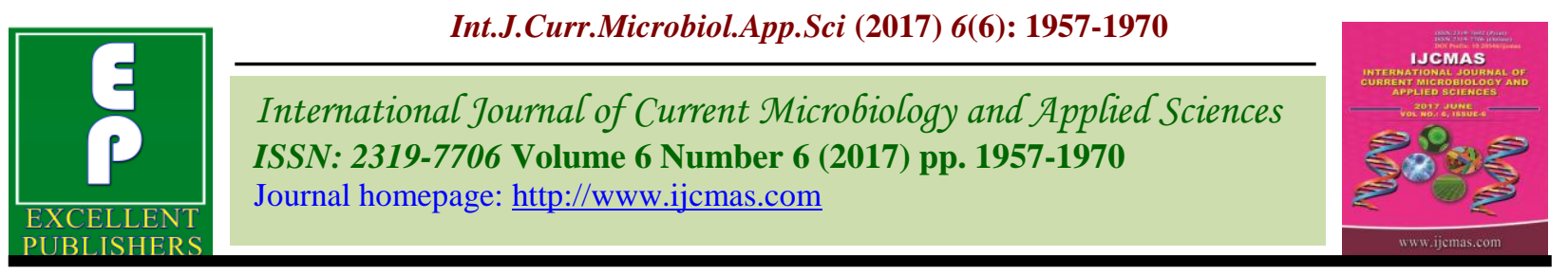

Review Article

https://doi.org/10.20546/ijcmas.2017.606.229

\title{
Environmental Monitoring in Offshore Areas
}

\author{
Sonali Kumbhare*, Dilip S. Ramteke and Pravin Charde
}

Sevadal Mahila Mahavidhyalaya, Nagpur, India

*Corresponding author

\section{A B S T R A C T}

Keywords

Environment,

Monitoring,

Pollution and

Marine water.

Article Info

Accepted:

23 May 2017

Available Online:

10 June 2017
The purpose of offshore environmental monitoring is to provide an overview of the environmental status and of trends over time seen in relation to offshore oil and gas activities. Monitoring is intended to indicate whether the environmental status is stable, deteriorating or improving, due to operator's activities. There is lot of pollution in sea due to discharge of various chemicals. So, it is very essential to study the pollution impact on the environment. This paper is detailing about how the environmental monitoring in offshore areas is carried out. Monitoring of Marine water environment is essential to know the pollutants generated from the oil extraction activity.

\section{Introduction}

Environmental Quality monitoring is an essential component of any environmental impact assessment study conducted for developmental activities. While assessing the likely impacts due to development of oil / gas fields and subsequent proposed production in offshore region, monitoring of Marine water environment is essential as it serves as the ultimate sink for all the pollutants generated from the oil extraction activity. In the offshore region, the data pertaining to oceanography, meteorology, physic-chemical characteristics of sea water, sediments, benthos, fishery resources and primary/secondary productivity of biological species in required to be generated.

The water quality monitoring factors that influence are:
Selection for Sampling locations

Type of Samples

Sampling Frequency

Number of Samples

Sampling Facilities

Sampling Equipment's for different parameters

Selection of Parameters

Samples collection frequency and size of sample

Preservation of samples for different parameters

Use of online analysers for in situ measurement/ on board analysis of field parameters (Non-conservative determinants which changes with time and could not be stabilized) 


\section{Selection of sampling location}

In offshore region, sampling location in such areas where the maximum activities (oil and gas fields, processing platforms, fishing zone, tanker loading and unloading, ship routes etc.) are in existence. Generally complete zone is selected. The zone is further divided into different grids and sampling is carried out at the centre of the grid as per the latitude and longitude. In Bombay, offshore areas (west coast) there are different oil and gas fields and processing platforms. Offshore drilling and oil processing activities are in the progress in that particular area. These activities are polluting aquatic environment upto certain extent however the major pollution may occur due to petroleum hydrocarbons release mainly by ballast water and tank washing aboard ships during transportation (1). So there is necessity of regular water quality monitoring. Figure 4 shows the offshore production areas along the coast line in the form of grid pattern after selecting the site.

\section{Sampling frequency}

Water samples should be collected at intervals so that no change in quality could pass unnoticed. The quality of water in various water bodies is rarely if ever constant in time but is subjected to change. The larger the number of samples from which the mean is derived, the narrower will be the limits of the probable difference between observed and the true values. However, the sampling schedule is a compromise between accuracy and the funds, personnel available for the work $(1,2)$.

\section{Sample collection}

Sample from various depths can be collected by using any of the sampler, commercially available. A wide range of indigenous automatic sampling equipments are also available for continuous sampling or at fixed intervals. Any sampling technique may be used; however, adaptation of a particular technique depends upon what is being sampled and what constituents are to be determined (3).

\section{Sample preservation}

Between the time that a sample is collected in the field and unit it is actually analysed in the laboratory, physical changes and chemical/ biochemical reactions, may take place in the sample container which will change the intrinsic quality of the sample. It is therefore necessary to preserve the samples to prevent or minimize their changes. This is done by various procedures such as keeping the samples in the dark, adding chemical preservatives (Table 1), lowering the temperature to related reactions by freezing of by a combination of the methods (4).

\section{Selection of parameters}

The selection of parameters is made according to the type of samples being collected in particular area. In general, the parameters are grouped in the following way:

Meteorological parameters: Temperature, Rainfall, Humidity

Physical parameter: Colour, Turbidity, dissolved Solids, conductivity

Chemical parameter: Inorganic and organic groups

\section{Inorganic group}

$\mathrm{pH}$, alkalinity, chloride, sulphate, sulphide, salinity and heavy metals like, $\mathrm{Fe}, \mathrm{Mn}, \mathrm{Cr}$, $\mathrm{Cu}, \mathrm{Pb}, \mathrm{Zn}$ and $\mathrm{Cd}$.

\section{Organic group}

Dissolved oxygen, bio-chemical oxygen demand, chemical oxygen demand, hydrocarbons and oil and grease. 
Nutrient parameters: Total nitrogen, nitrate nitrogen, total phosphate and orthophosphate

Biological parameters: Phytoplankton and zoo-plankton, water fowl, algae

Bacteriological parameter: total coliform, E. coli, Streptococci, Faecal coliform

A practical way to select suitable parameters for an individual water body is by means of a preliminary investigation programme, which provides an overview of the biological and chemical loads on the ecosystem.

\section{Marine abiotic environment}

Marine abiotic environment comprises two major components, viz. water column and sediments. It is important to study spatial and temporal variations in physic-chemical characteristics of water column for assessing the impacts due to discharges of drilling fluids, cuttings and produced water. The sediments act as major sink for accumulation of wastes hence it is required to study their characteristics for assessment of environmental impacts due to the drilling operations. Data on physic-chemical characteristics including levels of oxygen and nutrients, levels of heavy metals and hydrocarbons both in water column and sediments have therefore been required to be collated, critically reviewed and used for assessment of environmental quality (3).

\section{Water column}

Baseline environmental Quality of water column and sediments is mainly governed by hydrographical and meteorological features of the region which includes topographical features, winds, surface currents, water movements, waves, convergence and divergence zones and temperature. The water current and direction can be measured by lowering a water current meter DRDF from the vessel into sea at sampling point located at the centre of the grid under study and current speed and direction can be measured at various depths.

\section{Physico-chemical characteristics}

Seawater samples need to be collected at three depths (a) Surface, (b) Mid-depth of water column and (c) $2 \mathrm{~m}$ above the bottom of water column in each of the grid using Nishkin type sampler (Figure 5).

The field parameters can be estimated immediately onboard after sample collection whereas for other physico-chemical and biological parameters, 'samples can be processed and preserved following the standard procedures. Standard analytical methods (5) as enlisted in Table 2 are practiced for analyzing the preserved samples. Following are the significant Parameters to be analysed for marine water quality, monitoring.

\section{Turbidity}

Turbidity results due to suspended substances such as silt, clay and/or planktonic organisms. It restricts the penetration of sunlight and hence reduces photosynthesis which in turn is related to productivity of biomass. Suspended particles causing turbidity may also adsorb considerable amount of nutrient, viz. phosphate, potassium and nitrogen in their ionic forms and hence are not available for plankton production. Turbidity caused by colloidal particles of different thermal properties also influences the temperature conditions of the biomass by restricting the penetration and scattering of sunlight. The turbidity levels during post-monsoon are higher than pre-monsoon. High turbidity values during post-monsoon can be attributed to discharges to suspended solids load in the 
monsoon months coupled with resuspension of sediments caused by turbulence in the water column. Turbidity can be measured on board using a Hach or equivalent turbidimeter working on naphelometric principle.

\section{Salinity}

Salinity is a conservative parameter. It does not change with in-situ biochemical processes. Temporal and spatial variations in salinity are important to understand the dynamics of water column.

The salinity is estimated based on measurement of conductivity and chloride. Variation in surface salinity is caused by precipitation, evaporation and process mixing.

\section{pH}

$\mathrm{pH}$ of seawater varies between 7.0 and 8.5 indicating neutral to marginally alkaline conditions. Highly acidic or alkaline $\mathrm{pH}$ would be detrimental to biotic environment as well as biological processes occurring in the sea. The $\mathrm{pH}$ is measured on board using portable $\mathrm{pH}$ meter or by lowering a probe into water column at various depths for in situ measurements.

\section{Dissolved oxygen}

Dissolved oxygen in sea water is an essential requirement for the survival of aquatic organisms. The dissolved oxygen content from surface layers down to $50 \mathrm{~m}$ is more or less uniform. From $75 \mathrm{~m}$ downward there is a rapid decrease in the oxygen content and it attains the lowest value at a depth around $150 \mathrm{~m}$.

The DO is estimated on board either by Winkler method or by lowering the probe at depths and recording the DO value from portable DO meter.

\section{Nutrients}

In general, phosphate and nitrate show regular trend of distribution whereas nitrite shows an irregular pattern of distribution with depth. 'It is assumed that the depthwise and regional distribution of nutrient components and hydrographic parameters appear to be more depended on dilution, general current pattern and source of water masses. Samples for ammonia, nitrite, nitrate need to be preserved on board and be analysed using spectrophotometric methods or using probes with ISE and portable ionmeter.

\section{Heavy metals}

Heavy metals discharged during oil/gas exploration and extraction activities have been reported to cause great impact on marine environment due to their refractory nature. It has been established (6) that metals such as barium, cadmium, chromium, copper, lead and zinc are present in substantial concentration in drilling discharges. Spatial and temporal distribution as well as chemical forms of these metals in sea would influence the bioavailability and bioadsorption of these metals.

Samples for heavy metals are preserved with nitric acid immediately on board for total metals and for dissolved metals after filtration through $0.45 \mathrm{mu}$ filter paper. The estimation is carried out by either AAS or ICP after preprocessing the samples.

\section{Hydrocarbons}

Transport of crude oil and petroleum products across Arabian Sea amounts to 576 X 106 tonnes/year. This is about $54 \%$ of the total oil transported through marine waters in the world. Out of this $340 \mathrm{X} 106$ tonnes are carried to the Far East and Japan. Oil spilled annually at sea has been estimated as 2.2 to 4.9 million tonnes (7 and 8). 
Water samples should be collected in appropriate containers and analysed for hydrocarbons using carbon tetrachloride as solvent for extraction. Prior to analysis the extracts are subjected to treatment with silica gel for removal of organics other than hydrocarbons. Total petroleum hydrocarbons are then estimated using fluorescence spectroscopy (10). The reference standard is prepared using chrysene which represents petroleum hydrocarbons of natural origin as it cannot be biosynthesized. The photometric readings for extracts of samples are recorded at excitation and emission wavelengths of 318 $\mathrm{nm}$ and $362 \mathrm{~nm}$ respectively and the concentrations of hydrocarbons are determined using linear relationship of photometric data and standard hydrocarbon concentrations. The sequential procedure for hydrocarbon analysis of water sample is shown below.

\section{Sediments}

The marine environment is subjected to considerable stress through deliberate or accidental oil spills, ballast water discharges, dredging and infilling for coastal development, uncontrolled sewage and industrial wastewater discharges and oil and gas exploration activities. Most of the pollutants find their way to sediment which serve as sink. During drilling and development of oil and gas wells a wide variety of solids and liquids are produced on the platform, some of which are discharged directly into the ocean. Most of the inorganic elements potentially toxic to benthic biota will eventually reach the sediments. Continuous discharges of solid and liquid from platform will have significant impacts on meio and macro benthic biota $(9,10)$.

\section{Heavy metals}

Marine sediments have been identified as the necessary component of the Marine Pollution
Monitoring System, due to the fact that sediments represent the single biggest repository of metals in the marine environment and fluxes of metals to and from sediments are important considerations in mass balance calculations of trace metals.

The sediment samples should be collected using Van Veen grab sampler (Figure 3) and stored in aluminium foils and preserved at low temperature $\left(-30^{\circ} \mathrm{C}\right)$ to prevent decomposition and /or degradation of sediments. The sediment samples further analysed for physico-chemical characteristics, heavy metals, hydrocarbons and benthic organisms. While analyzing for heavy metals and physic-chemical parameters, the samples should be dried at prevailing room temperature and homogenized in a mortar and sieved. The preweighed sieved samples should be digested with strong acid, extracted and analysed for various parameters including heavy metals (4).

\section{Hydrocarbons}

The presence of hydrocarbons in sediments of offshore region can be considered as the indicator of pollution due to drilling and production activities that have undertaken. Additionally, hydrocarbons can also originate from urban and industrial effluents, accidental oil tanker discharges and discharges from ships sailing along the trade and tanker routes. Therefore identification of a specific source of hydrocarbon discharging into sea can be done only if data on composition of hydrocarbon from these sources are available and are correlated with the measured values.

In order to analyze hydrocarbons in sediments each preweighed sediment samples should be placed in soxhlet apparatus and refluxed for 8 hours using mixture of methanols and benzene (1:1 as solvent). The extracts obtained on refluxing should be subjected to preconcentration in a rotary evaporation and 
individually passed through column of silica gel for removal of organics other than hydrocarbons and estimated using infrared spectroscopy at $2930 \mathrm{~cm}-1$ wavenumber (II). The sequential procedure for hydrocarbons estimation in sediment is given below:

\section{Marine biotic environment}

Biotic environment comprises microorganism, phytoplankton, zooplankton, benthos and nekton. While phytoplankton are limited to the photic zone, other marine animals tend to move away from this zone. Further, geographic distribution of plankton depends on the habitat, water currents and the tolerance of organisms as water circulates in gyre systems.

Biological productivity of the ocean is influenced by factors, viz. light, nutrients, primary, secondary and tertiary production. Light penetration in the ocean determines the depth of the photosynthetic zone whereas the nutrients particularly nitrogen and phosphorus influence the promotion of productivity. Phytoplankton or the planktonic algae give the production at the primary stage of the food chain while zooplankton and fish are at the secondary and tertiary levels of the food chain.

Fig.1 Sequential procedure for hydrocarbon analysis of water samples

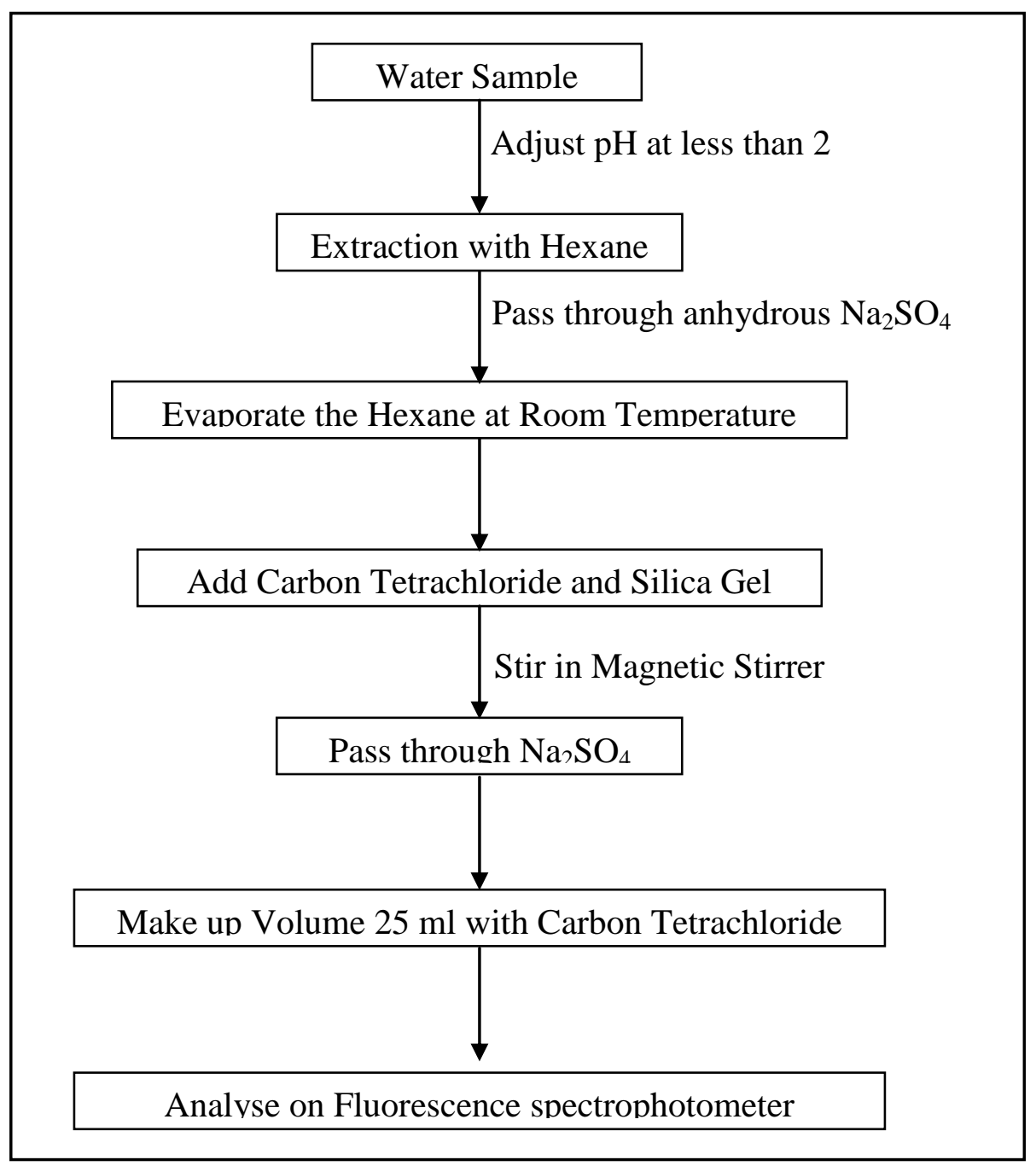


Fig.2 Sequential procedure for hydrocarbon estimation in sediments

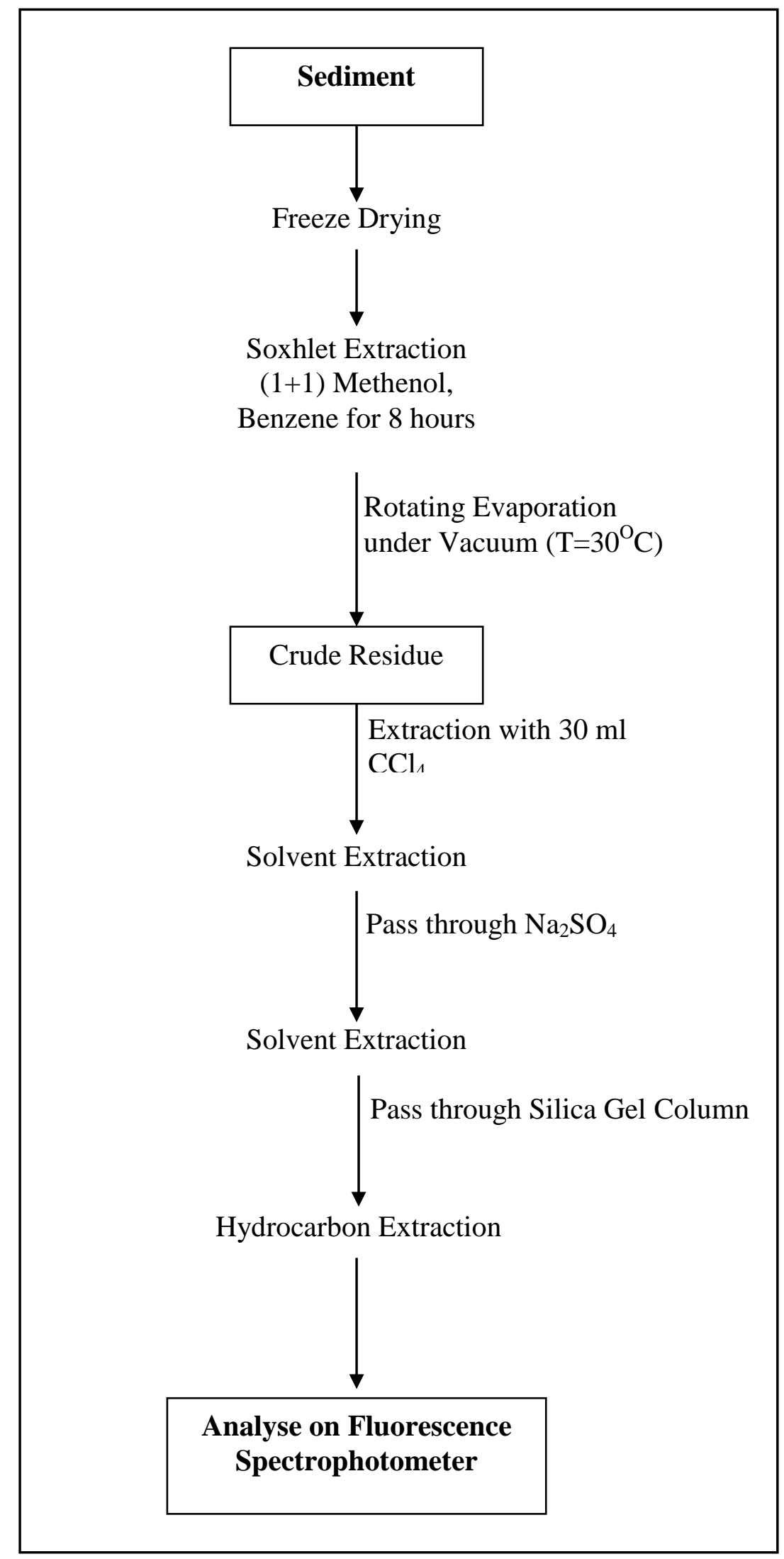


Fig.3 Sequential procedure for hydrocarbon estimation in fish tissues

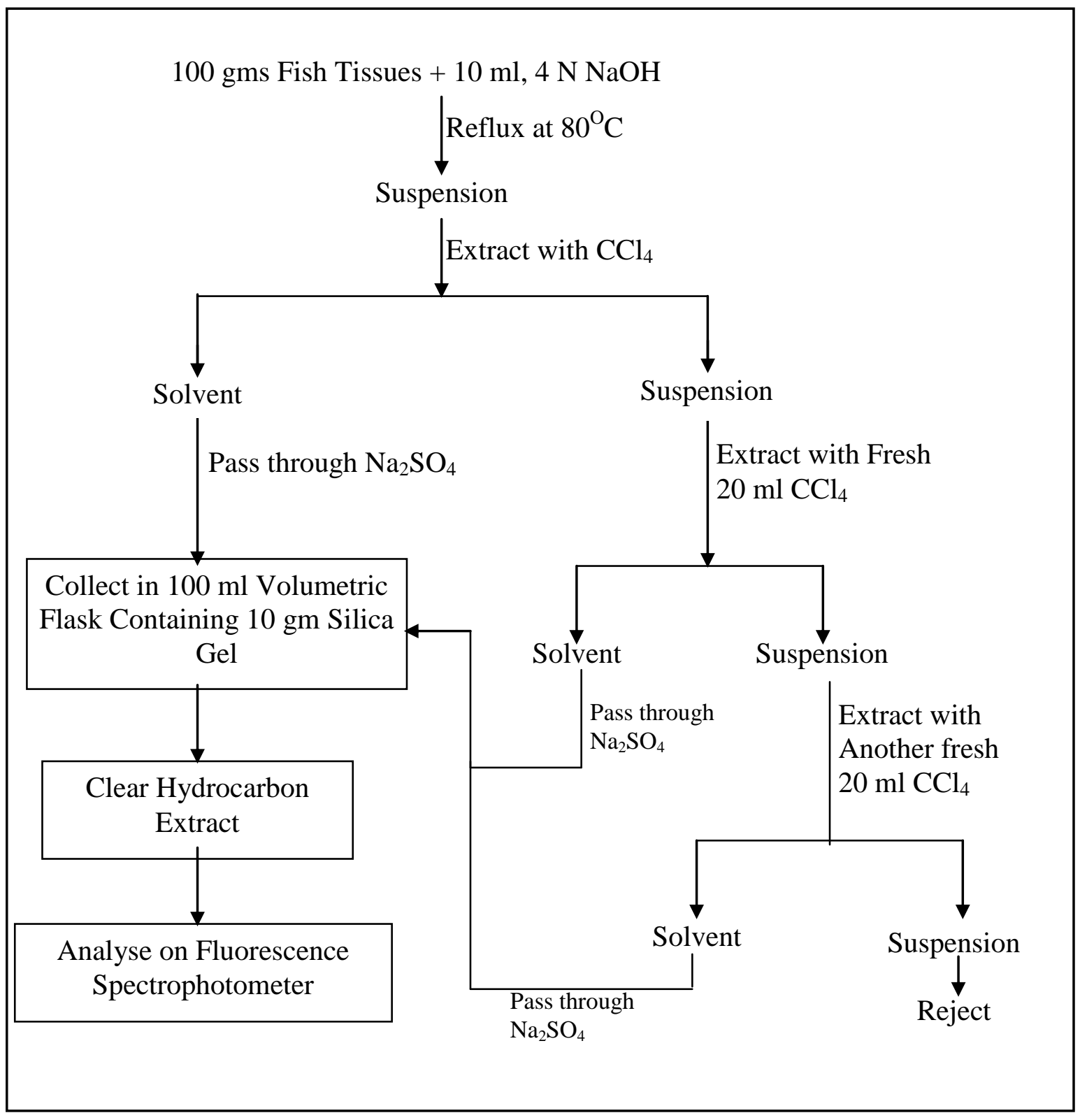


Fig.4 Water quality monitoring stations

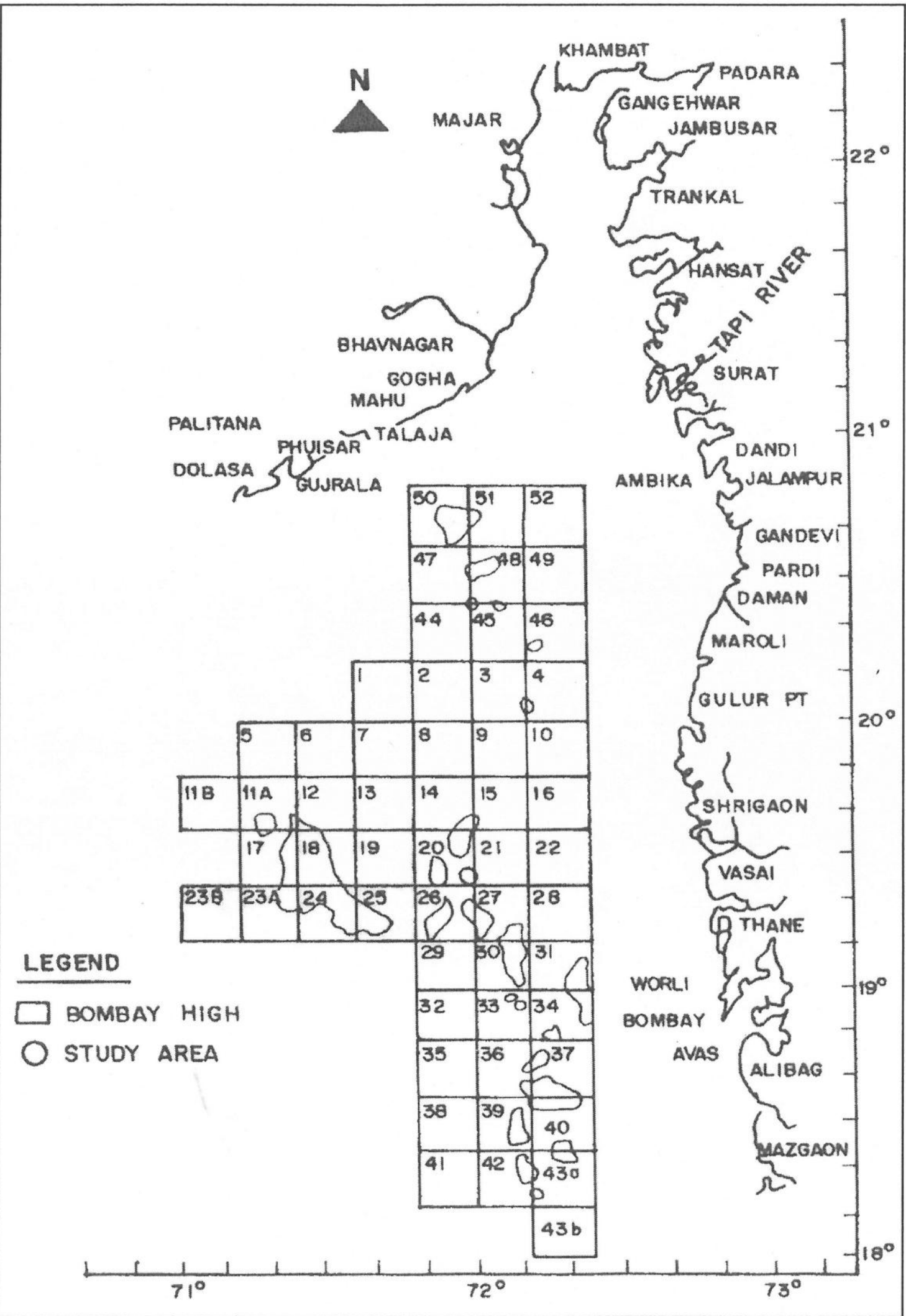


Fig.5 Nisikin type water sampler with reversible thermometer

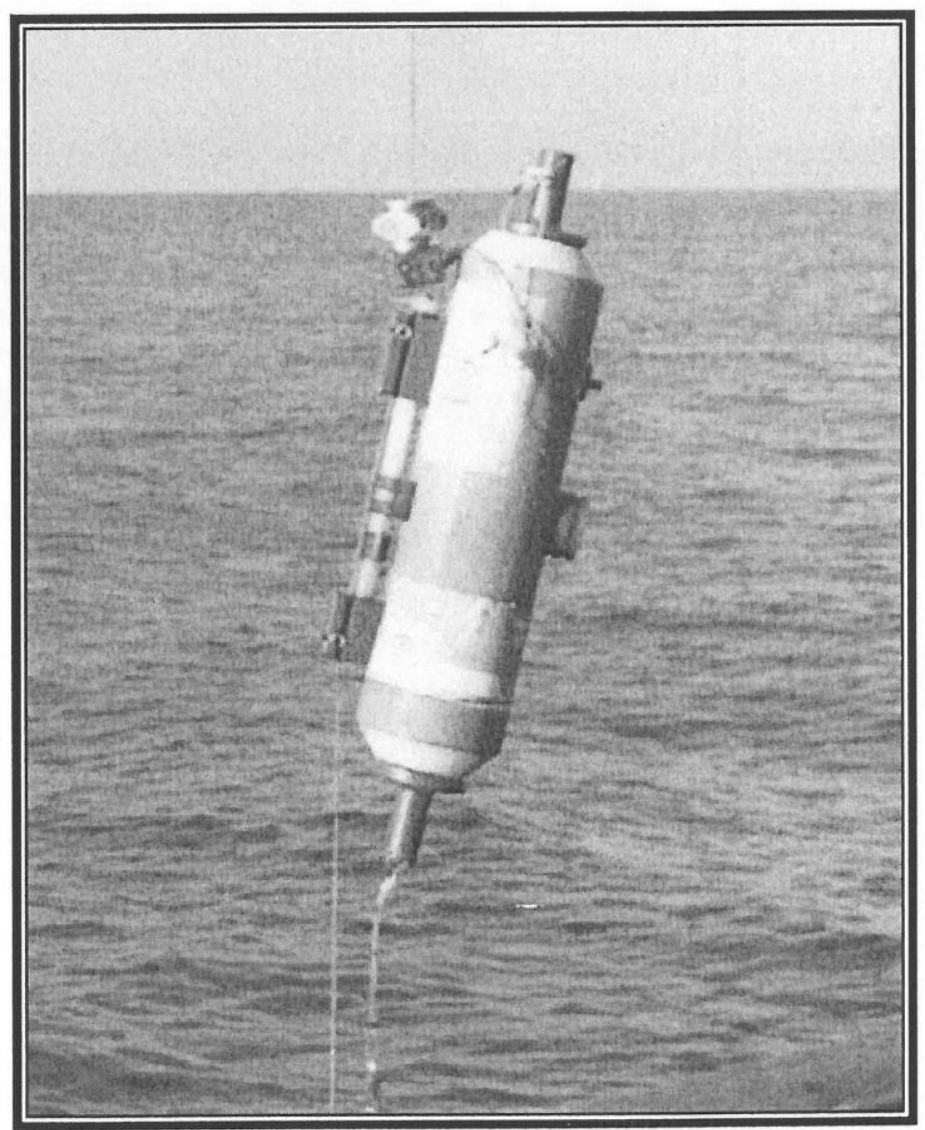

Fig.6 Van Veen Grab sampler

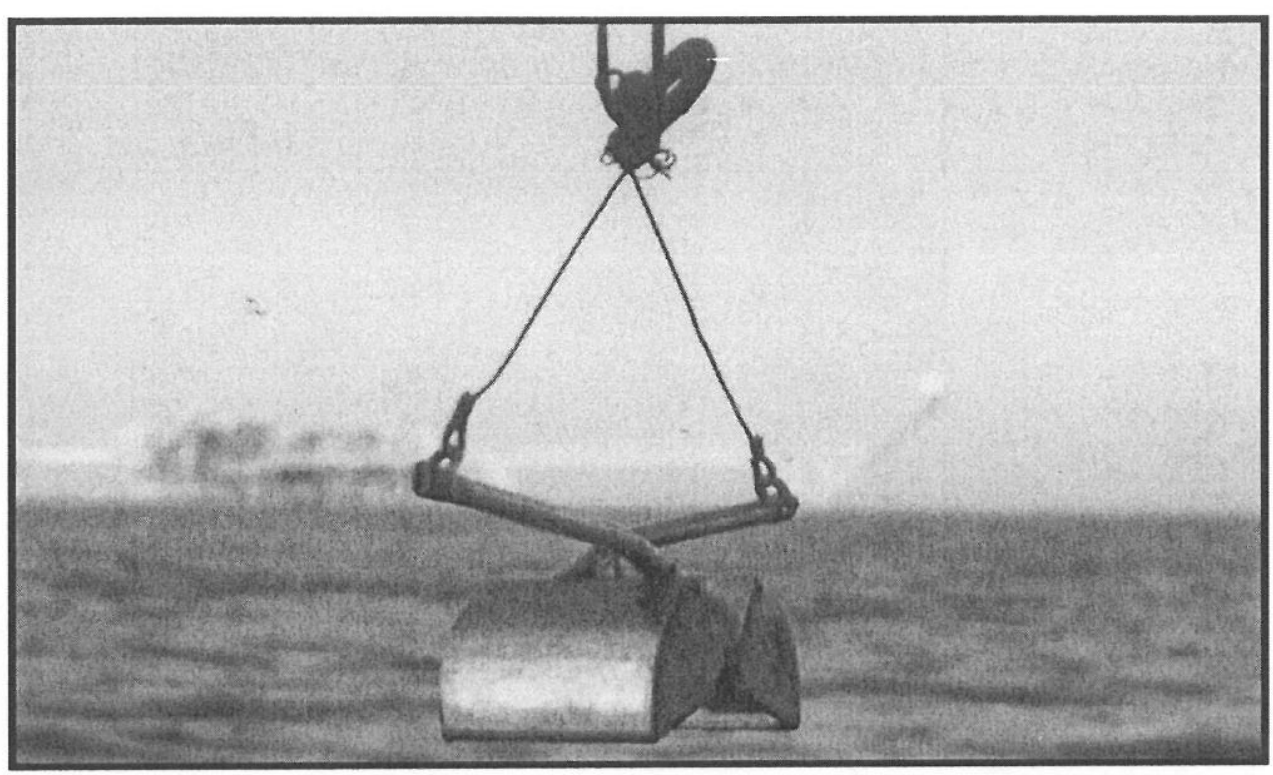


Fig.7 H. T. Net for plankton collection

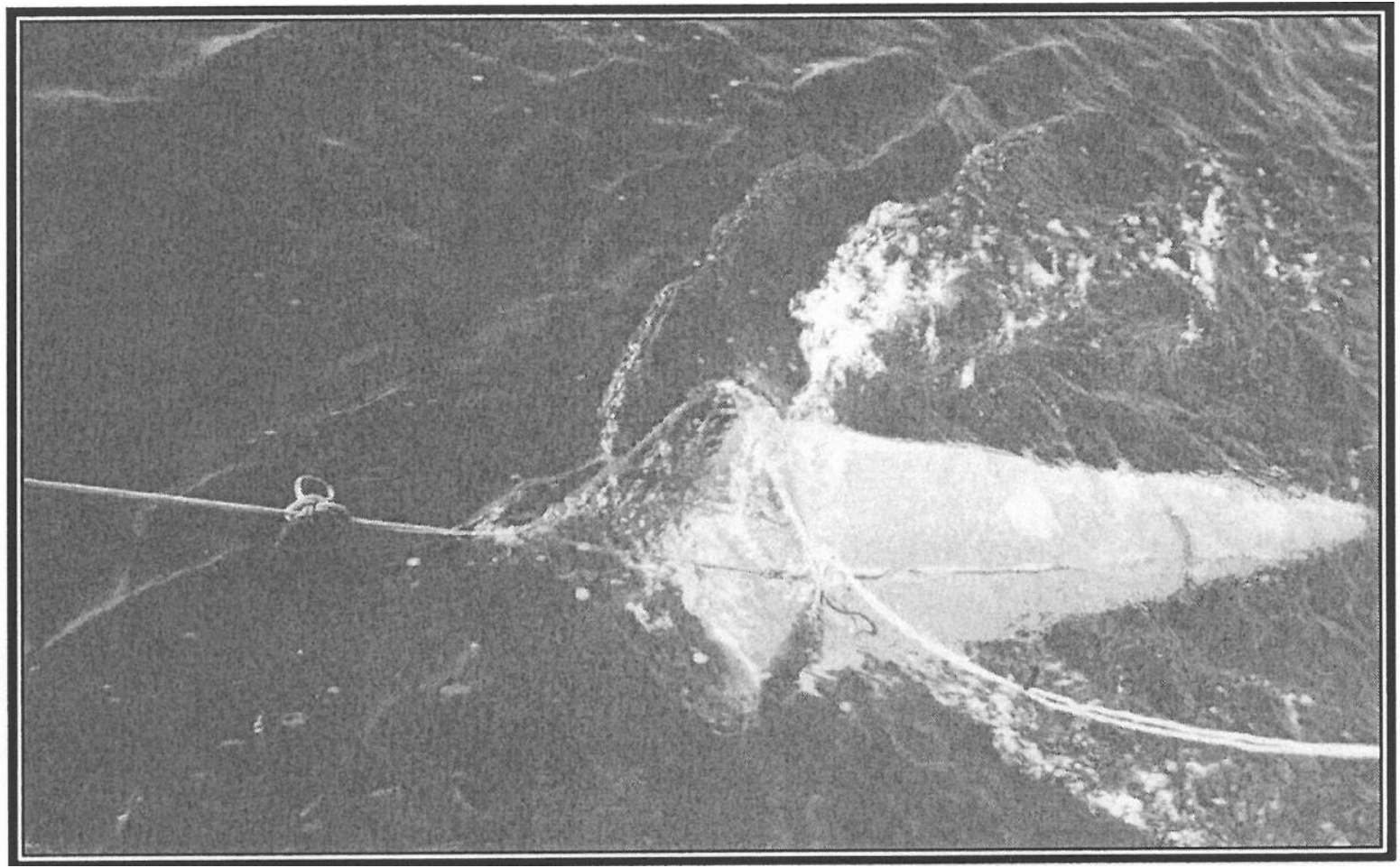

Table.1 Sampling containers and preservation

\begin{tabular}{|c|c|c|c|}
\hline Sr. No. & Determination & Container & Preservation \\
\hline 1. & Temperature & Polyethylene or Glass bottle & Analyze immediately \\
\hline 2. & Turbidity & Polyethylene or Glass bottle & $\begin{array}{l}\text { Analyze same day, store in } \\
\text { dark up to } 24 \mathrm{hrs}\end{array}$ \\
\hline 3. & Total Solid & Polyethylene or Glass bottle & Refrigerate \\
\hline 4. & Total Dissolved solid & Polyethylene or Glass bottle & Refrigerate \\
\hline 5. & $\mathrm{pH}$ & Polyethylene or Glass bottle & Analyze immediately \\
\hline 6. & Alkalinity & Polyethylene or Glass bottle & Refrigerated \\
\hline 7. & Salinity & Glass bottle, wax seal & Analyze immediately \\
\hline 8. & Sulphide & Polyethylene or Glass bottle & $\begin{array}{l}\text { Refrigerate, acid } 4 \text { drops } 2 \\
\text { N Zinc acetate/ } 100 \mathrm{ml}\end{array}$ \\
\hline 9. & Sulphate & Polyethylene or Glass bottle & Refrigerate \\
\hline 10. & Nitrate & Polyethylene or Glass bottle & Refrigerate, analyze soon \\
\hline 11. & Phosphate & $\begin{array}{l}\text { Glass bottle (Rinsed with } 1+1 \\
\mathrm{HNO}_{2} \text { ) }\end{array}$ & \\
\hline 12. & Dissolved oxygen & Glass, BOD bottles & Analyze immediately \\
\hline 13. & BOD & Polyethylene or Glass bottle & Refrigerate \\
\hline 14. & COD & Polyethylene or Glass bottle & Add $\mathrm{H}_{2} \mathrm{SO}_{4}$ to $\mathrm{pH}<2$ \\
\hline 15. & Oil and grease & Glass, wide - mouth calibrated & $\begin{array}{l}\text { Add } \mathrm{H}_{2} \mathrm{SO}_{4} \text { to } \mathrm{pH}<2, \\
\text { Refrigerate }\end{array}$ \\
\hline 16. & Hydrocarbon & Glass bottle & Refrigerate \\
\hline 17. & Metals & Glass bottle & Add $\mathrm{HNO}_{3}$ to $\mathrm{pH}<2$ \\
\hline
\end{tabular}


Table.2 Physico-chemical analysis and methodology

\begin{tabular}{|c|c|c|}
\hline Sr. No. & Parameters & Method \\
\hline 1. & Alkalinity & Titrimetric Method/ Electrometric Method \\
\hline 2. & Chloride & Argentometric Titration Method \\
\hline 3. & Silica & Spectrophotometric method \\
\hline 4. & Sulphate & Turbidimetric Method \\
\hline 5. & Nitrate & $\begin{array}{l}\text { Spectrophotometric method or UV Spectrophotometric } \\
\text { method }\end{array}$ \\
\hline 6. & Phosphate & Ammonium Molybdate Spectrophotometric method \\
\hline 7. & Heavy Metals & Atomic Absorption Spectrophotometric method or ICP \\
\hline 8. & Oil and Grease & Partition GravematricSoxhiet Extraction Method \\
\hline 9. & Dissolved Oxygen & Winkler's Modified Method \\
\hline 10. & $\begin{array}{l}\text { Chemical Oxygen } \\
\text { Demand }\end{array}$ & Open/ Closed Refluxing followed by Titration with FAS \\
\hline 11. & $\begin{array}{l}\text { Bio-Chemical } \\
\text { Oxygen Demand }\end{array}$ & 5 days $20^{\circ} \mathrm{C}$ (Do estimation by winkler Method) \\
\hline 12. & Nitrogen (Total) & Digestion followed by distillation and Titrimetric Method \\
\hline 13. & Sulphide & Iodometric Method \\
\hline 14. & Hydrocarbons & $\begin{array}{l}\text { Fluorescence Spectrophotometric or } \\
\text { Spectrophotometric Method }\end{array}$ \\
\hline
\end{tabular}

\section{Phytoplankton}

Phytoplankton, mostly the unicellular organisms are either solitary or colonial. These autotrophs synthesize organic materials from inorganic substance in the presence of sunlight through the process of photosynthesis. Consequently, the depth of penetration of the light in seawater controls this process. Phytoplankton provide food for herbivores and hence form a major link in the food chain.

Samples for phytoplankton analysis should be collected from surface by vertically hauling the sample bucket. $750 \mathrm{ml}$ of sample should be stored in $4 \%$ neutral formalin. The samples are then concentrated using centrifuge and further examined under microscope to identify the species and their number. This data is further used for determining Shannon Weaver Diversity Index of individual sampling location (12).

\section{Zooplankton}

Zooplankton form an important link in food chain and act as both primary conswner of marine aquatic ecosystem and a food source for many aquatic organisms including fishes. Unlike the freshwater zooplankton, the marine zooplanktons show considerable diversity as it is composed of members of every group from protozoa to chordata. Depending on seasons the plankton community show pronounced variation in its character and composition.

The zooplankton are indicators of the general fertility and water quality of a sea area. An imbalance in its population structure could bring about far reaching effects on the dependent fishery resources. The imbalance could be brought about by natural as well as man-made reasons. Fluctuations in the environmental conditions resulting in poor upwelling, rise in sea surface temperature, 
underwater disturbances, altered monsoons and water currents from natural causes affect zooplankton productivity and species diversity while pollution especially due to oil spills represent one of the major man-made causes.

Samples should be collected using H.T. plankton net (300 microns) to represent all the available groups of zooplankton through a horizontal haul for $15 \mathrm{~min}$ duration at constant speed in each grid (Figure 6). Thesamples are to be fixed immediately with 5 percent formalin solution.

\section{Benthos}

The organisms which inhabit the bottom of aquatic body are known as benthos. Many of them are sessile, some creep over or burrow in mud and base of water body.

The quality and quantity of animals found at the bottom is not only related to the nature of substrata but also to the depth and type of aquatic plants present in such an environmental. Their number and distribution also depend upon physic-chemical characteristics of water and biological complexes such as food and other factors.

The bottom mud can be collected from various sampling points by Van Veen grab of $250 \mathrm{~cm} 2$ size. For macrobenthos the sediment is sieved through $500 \mu$ sieve and the organisms retained on the sieve are preserved immediately with 4 percent neutral formalin (without rose bengal).

A subsample of sediments is passes through $50 \mu$ sieve for segregation of meiobenthos. The sediments along with meiobenthos retained on $50 \mu$ sieve are preserved immediately for subsequent analyses in the laboratory (3).

\section{Fisheries}

India with $6100 \mathrm{~km}$ long coastline, continental shelf of 0.451 million sq. $\mathrm{km}$ and exclusive economic zone (EEZ) of 2.02 million sq.km has rich marine fishery potential. It is also established that coastal waters particularly off west coast are highly productive and act as spawning and nursery grounds for several commercially important fish species.

Existing fish species should be collected and identified by operating a bottom trawl net in" different locations by dividing the study area into uniform grid size. Fish catch should be weighed to estimate the yield of the individual species. The tissues viz. muscles, gonad, liver and gills are dissected out. Each of the tissues are weighed and preserved deep frozen for subsequent analysis (Heavy metals and hydrocarbons) in the laboratory (14). The sequential procedure for hydrocarbon estimation in fish tissues is given below:

\section{Prevention of sample contamination}

Field measurements should always be made on separate sub-sample which is to be discarded once the measurement have been made.

Sample bottles, new or used, must be cleaned according to the recommended methods.

Water sample bottle should be employed for water samples only. Laboratory bottles to store concentrated reagents should never be used.

Recommended preservation methods must be used. All preservatives must be of analytical grade.

The inner portion of the sample bottle and caps should not be touched with bare hands. 
Sample bottle must be kept in a clean environment, away from dust, dirt, fumes and grime

Petroleum products (gasoline, oil exhaust fumes) are prime sources of contamination, Spills or drippings must be removed immediately.

Filter units and related apparatus must remain sterile, until the sample is collected

Specific conductance should never be measured in the sample water that was first $\mathrm{pH}$ measurement.

Samples must never be permitted to stand in the sun; they should be stored in cool place, ice chests are recommended

Samples must be transferred to laboratory without delay

Additional sampling precautions are required to be taken depending upon samples conditions at a particular location.

\section{References}

Reeve, R. N., (2002); "Introduction to Environmental Analysis" John Wiley and sons; England, PP 11-22

APHA, AWWA and WEF (1998); "Standard Methods for Examination of water and wastewater" $20^{\text {th }}$ Edition, Editor: clesceri Lonare S; Green berg Arnold E and Eaton Andrew.

Garg, J.S; (1988), "Environmental politics and Monitoring around oil Platform," Mar. Poll. Bull, 19(11); PP 549-550

Ramteke D.S, Moghe C.A. and Sarin R, (2002); "Water and Wastewater Analysis" Ed.
Kaul S.N. and Ashutosh Guatam; Daya Publishing House, New Delhi

Method of Soil analysis, Part - 11, American Society of Agronomy, ING publishers, Madison, Wisconsin USA (1965)

Long-term Environmental effects of offshore oil and gas development, edited by D.F. Boesch and N.N. Rubalais, Elsevier Applied Science Publishers Ltd. (1987)

EPA (1985), "Assessment of Environmental Fate and Effects of Discharges from offshore oil and Gas operations" EPA 440/4-85/002

Monaghan et.al. (1980) "Marine Environmental Pollution" Elsevier Science Publication Vol. I PP 413-431

Birket L, and Mc Intyre A.D, (1971); "Methods for study of marine Benthos" ed, by Halme N.A. and Mc lntyre A.D; Black well Sci, Publ. Oxford; PP-157

Anon (1992), "Determination of petroleum hydrocarbons in sediments" Reference method for Marine pollution studies No. 20 (UNDP, Geneva) PP-17.

Law R.J. (1981); "Hydrocarbons concentration is waters and sediments from UK marine waters, Determined by Fluorescence Spectroscopy" Marine poll. Bull; 12(5); PP 153-157

Vernberg F - John et.al. (ed) (1981); "Biological Monitoring of Marine Pollutants," Academic Press, New York

Saha M.K. and Konar S.K. (1983), "Acute Toxicity of some petroleum pollutants to plankton and fish. Environment and Ecology 1(2) PP 117-119

Saha M.K. (1983), "Toxicity of petroleum products to plankton and fish" Environment and Ecology" 1(7) PP 61-62.

\section{How to cite this article:}

Sonali Kumbhare, Dilip S. Ramteke and Pravin Charde. 2017. Environmental Monitoring in Offshore Areas. Int.J.Curr.Microbiol.App.Sci. 6(6): 1957-1970. doi: https://doi.org/10.20546/ijcmas.2017.606.229 